Supplement of Solid Earth, 12, 275-298, 2021 https://doi.org/10.5194/se-12-275-2021-supplement (C) Author(s) 2021. This work is distributed under the Creative Commons Attribution 4.0 License.

(c) (1)

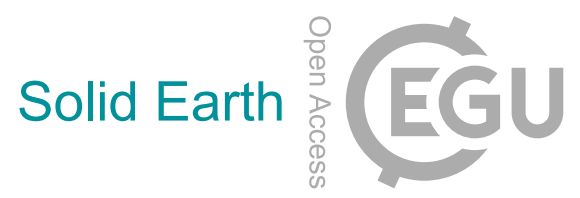

Supplement of

\title{
The preserved plume of the Caribbean Large Igneous Plateau revealed by 3D data-integrative models
}

\author{
Ángela María Gómez-García et al. \\ Correspondence to: Ángela María Gómez-García (angela@gfz-potsdam.de)
}

The copyright of individual parts of the supplement might differ from the CC BY 4.0 License. 


\section{S1. Mantle density effect on the gravity signal}

Table S1 has a compilation of the four tested mantle density configurations. Model 1 (M1) aims to evaluate the signal of the densities obtained from the conversion of S-wave velocities, without considering any other slab shape. Model 2 (M2), instead, includes the Slab2 thickness, with a density of $3163 \mathrm{~kg} \mathrm{~m}^{-3}$, that was obtained with the inversion algorithm available in IGMAS+ (Sæther, 1997; Schmidt et al., 2011). In this model, a mantle with a constant density of $3200 \mathrm{~kg} \mathrm{~m}^{-3}$ is assumed. Model 3 (M3) testes an integration of both the 3D mantle densities and the Slab2 information. Finally, Model 4 (M4) evaluates the gravity response of the 3D mantle densities in addition to the integration of the Nazca and Caribbean slabs geometries, as represented in Fig. 3 (f). When both slabs are integrated into the model, a density of 3163 $\mathrm{kg} \mathrm{m}^{-3}$ is obtained with the IGMAS+ inversion algorithm. For all models, the mantle density between the Moho and $50 \mathrm{~km}$ depth is considered constant, with a value of $3200 \mathrm{~kg} \mathrm{~m}^{-3}$.

Table S1. Summary of the datasets used to constrain the initial 3D lithospheric-scale model of the South Caribbean and northwestern South American plate, and the density values $\left(\mathrm{kg} \mathrm{m}^{-3}\right)$ assumed for each layer on the tested models.

\begin{tabular}{|c|c|c|c|c|c|}
\hline Layer & M1 & M2 & M3 & M4 & Reference of structural layer \\
\hline Water & \multicolumn{4}{|c|}{1040} & GEBCO (Weatherall et al., 2015) \\
\hline Oceanic sediments & \multicolumn{4}{|c|}{2350} & CRUST1.0 (Laske et al., 2013) \\
\hline $\begin{array}{l}\text { Continental } \\
\text { sediment }\end{array}$ & \multicolumn{4}{|c|}{2500} & \\
\hline Oceanic crust & \multirow{2}{*}{\multicolumn{4}{|c|}{$\begin{array}{l}2900 \\
2800\end{array}$}} & Moho depth from GEMMA model \\
\hline Continental crust & & & & & (Reguzzoni and Sampietro, 2015) \\
\hline $\begin{array}{l}\text { Nazca slab } \\
\text { Caribbean slab }\end{array}$ & - & $\begin{array}{c}3163 \\
-\end{array}$ & $\begin{array}{c}3163 \\
-\end{array}$ & 3163 & $\begin{array}{l}\text { Slab2 (Hayes et al., 2018) } \\
\text { (Mora et al., 2017) }\end{array}$ \\
\hline $\begin{array}{l}\text { Mantle from Moho } \\
\text { down to } 50 \mathrm{~km} \\
\text { depth }\end{array}$ & \multicolumn{4}{|c|}{3200} & - \\
\hline $\begin{array}{l}\text { Mantle from } 50 \\
\text { down to } 200 \mathrm{~km} \\
\text { depth }\end{array}$ & $\begin{array}{l}\text { 3D density } \\
\text { solution }\end{array}$ & 3200 & $\begin{array}{l}\text { 3D density } \\
\text { solution }\end{array}$ & $\begin{array}{l}\text { 3D density } \\
\text { solution }\end{array}$ & $\begin{array}{l}\text { SL2013sv tomographic model } \\
\text { (Schaeffer and Lebedev, 2013) }\end{array}$ \\
\hline
\end{tabular}

Figure S1 (a) to (d) presents the residuals of the four different tested mantle configurations, with their associated RMSE. The densities assumed on each case are summarised in Table S1. The residuals of model M1 (Figure S1 (a)), in which only the 3D mantle density variation based on S-wave velocities was considered, are characterised by broadly distributed negative values over the western South American continent. These negative residuals suggest that the modelled densities are overestimated, or in other words, that there is a mass excess in the initial model. The overall misfit is represented by a RMSE of 37.72 mGal, the highest of all evaluated models.

The configuration assumed in model $\mathrm{M} 2$ includes a constant mantle and the Nazca slab geometry, which gives as a result large positive residuals (Figure S1 (b)) over the western most corner of South America, suggesting a mass deficit in the model. These residuals have a RMSE of $31.77 \mathrm{mGal}$, approximately $6 \mathrm{mGal}$ smaller than the RMSE of the residuals obtained with model M1. 
On the other hand, the spatial trend of the residuals obtained with models M3 and M4 are similar to each other (Figure S1 (c) and (d)). However, model M4 in which both the Nazca and the Caribbean subductions are taken into account, in addition to the 3D density solution for the mantle, shows the minimum RMSE of all tested configurations ( $28.84 \mathrm{mGal})$.

Based on these results, it is possible to evaluate the impact that the mantle density configuration has in the modelled gravity anomalies. In fact, in terms of the RMSE, solving the mantle with both the 3D density distribution and the Nazca and Caribbean slabs (model M4) implies a reduction of $23.5 \%$ in the RMSE, compared with a model that only considers the 3D mantle solution (model M1). For this reason, the model M4 was selected as the initial lithospheric-scale density configuration. The wavelength of the residuals associated to this model (Figure S1 (d)) indicate that they are due to shallow heterogeneities that were not considered in the initial set up of the model. Therefore, this initial configuration is used to have better insights regarding the continental and oceanic crystalline crustal structures, as well as the uppermost lithospheric mantle.
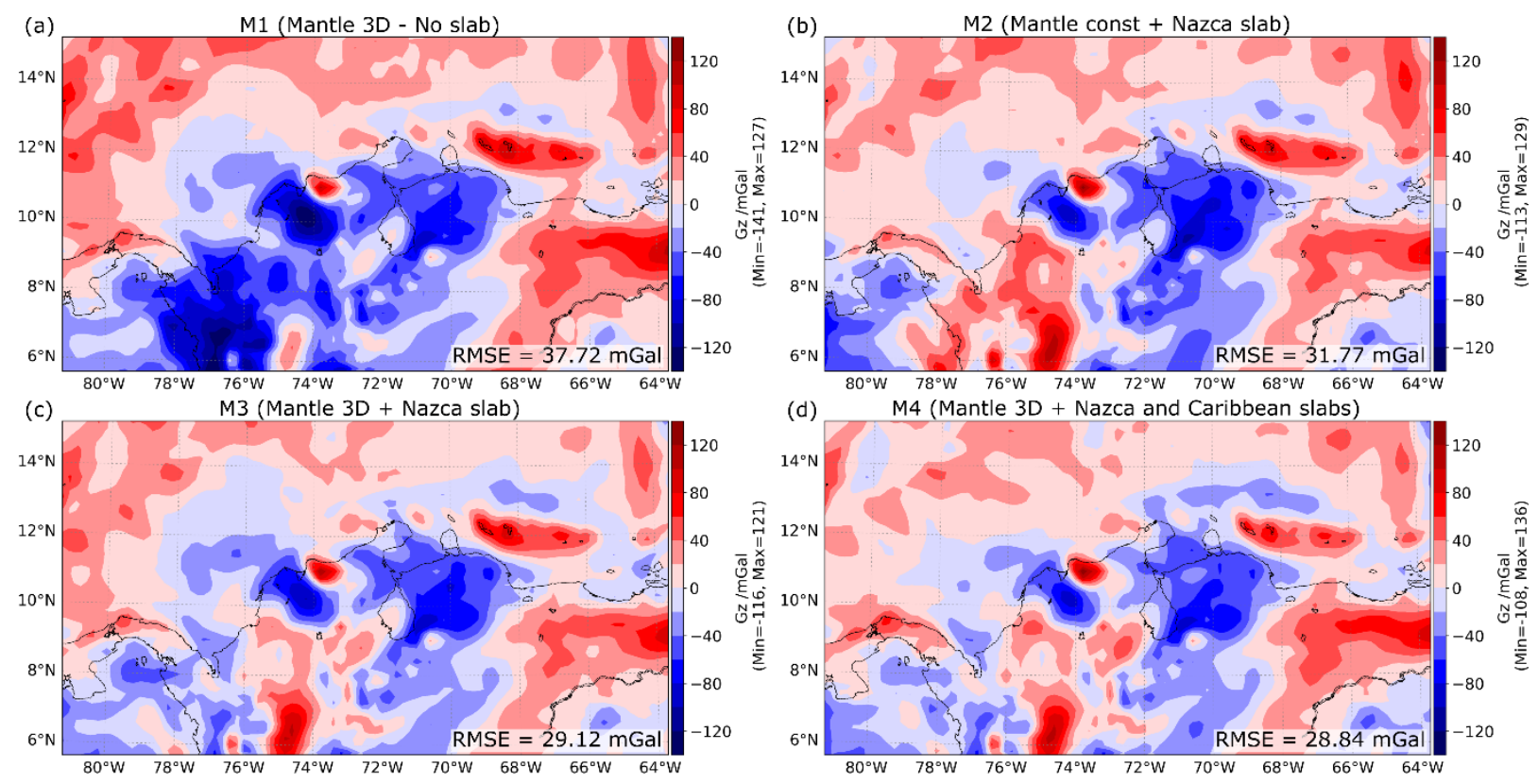

Figure S1. The gravity residuals allow to test the effect of the four different mantle configurations on the modelled gravity anomalies. Gravity residuals for: (a) Model M1, (b) Model M2, (c) Model M3 and (d) Model M4. See Table S1 for a detailed description of the tested mantle density distributions. Figure $\mathbf{S 5}$ depicts the statistics and the associated histograms for the residuals of each model. 


\section{S2. Individual geometries of the Nazca and Caribbean slabs used in some of the tested configurations}

(a)

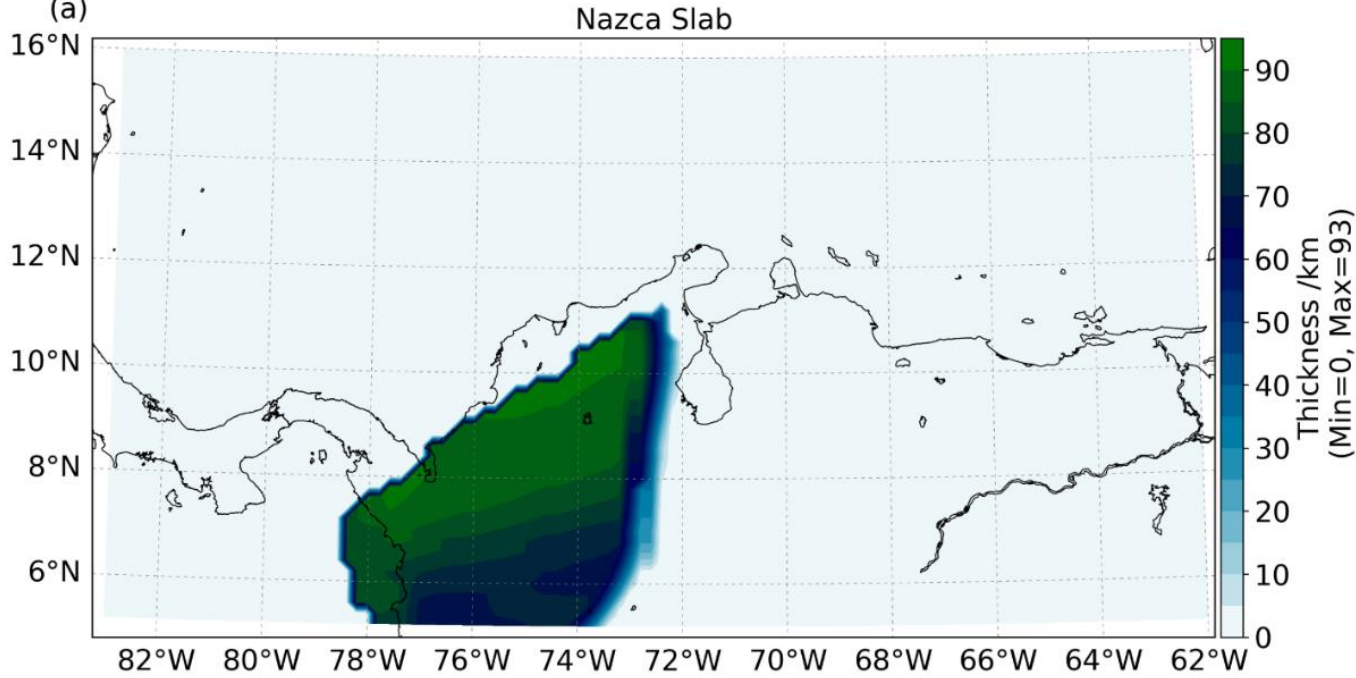

(b)

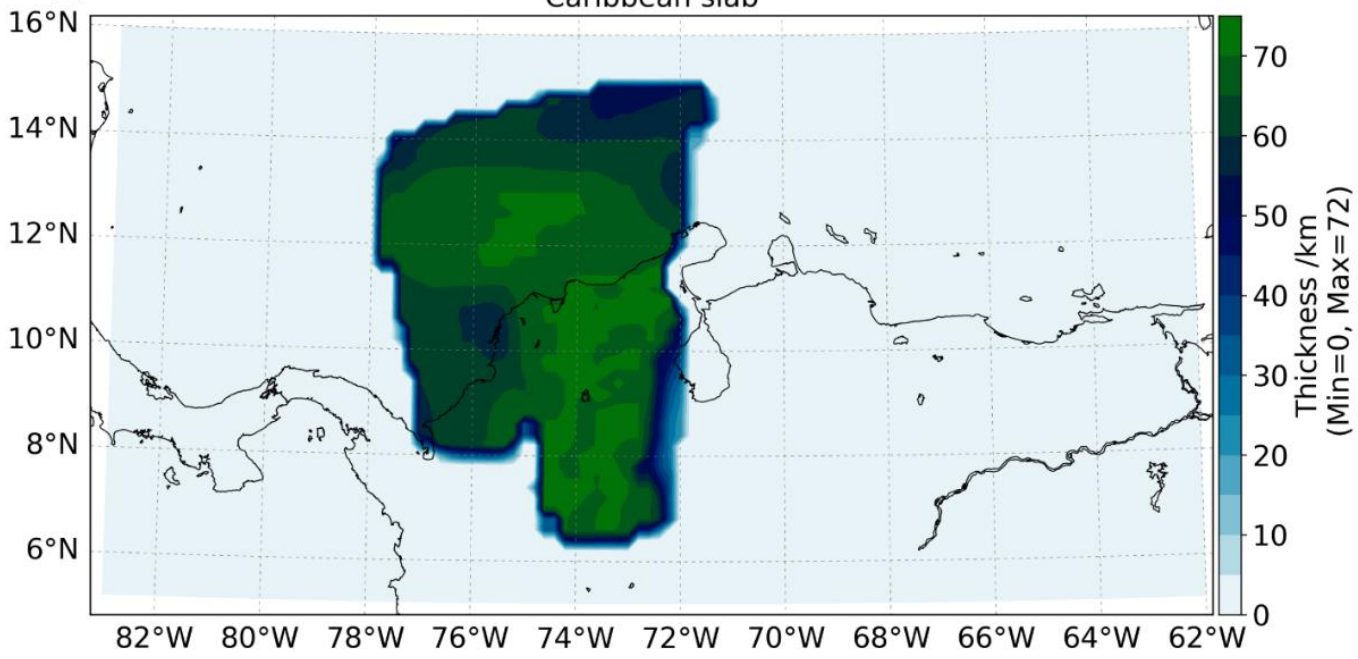

Figure S2. Slabs geometries implemented on the lithospheric-scale model. (a) Nazca slab from Hayes et al. (2018). (b) Caribbean slab proposed by Mora et al. (2017). The thickness of the Caribbean slab was a-priori defined by displacing the top surface down to $70 \mathrm{~km}$ depth. 
S3. Conversion from S-wave velocities into mantle densities based on Gómez-García et al. $(2019 a, b)$
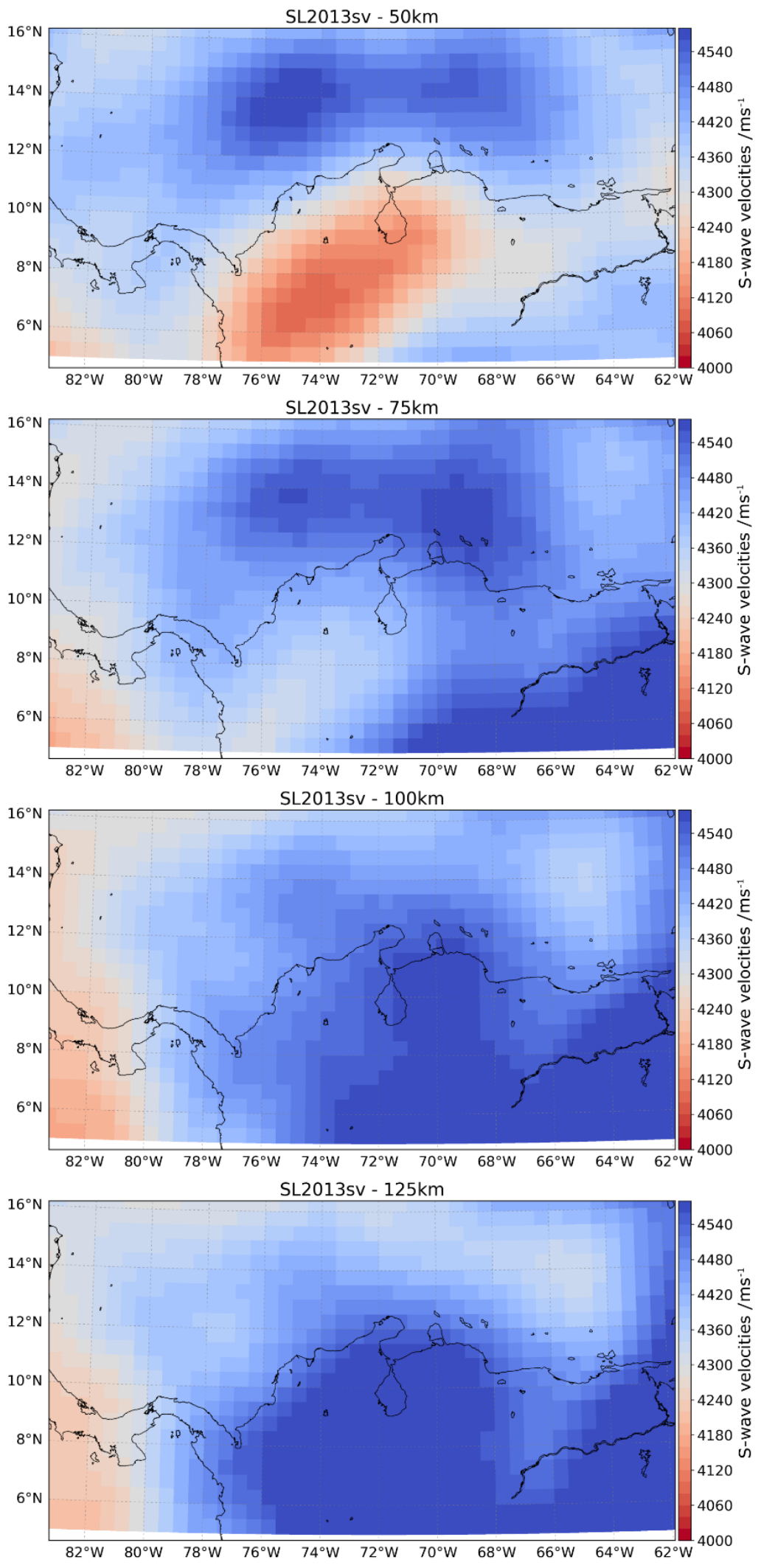

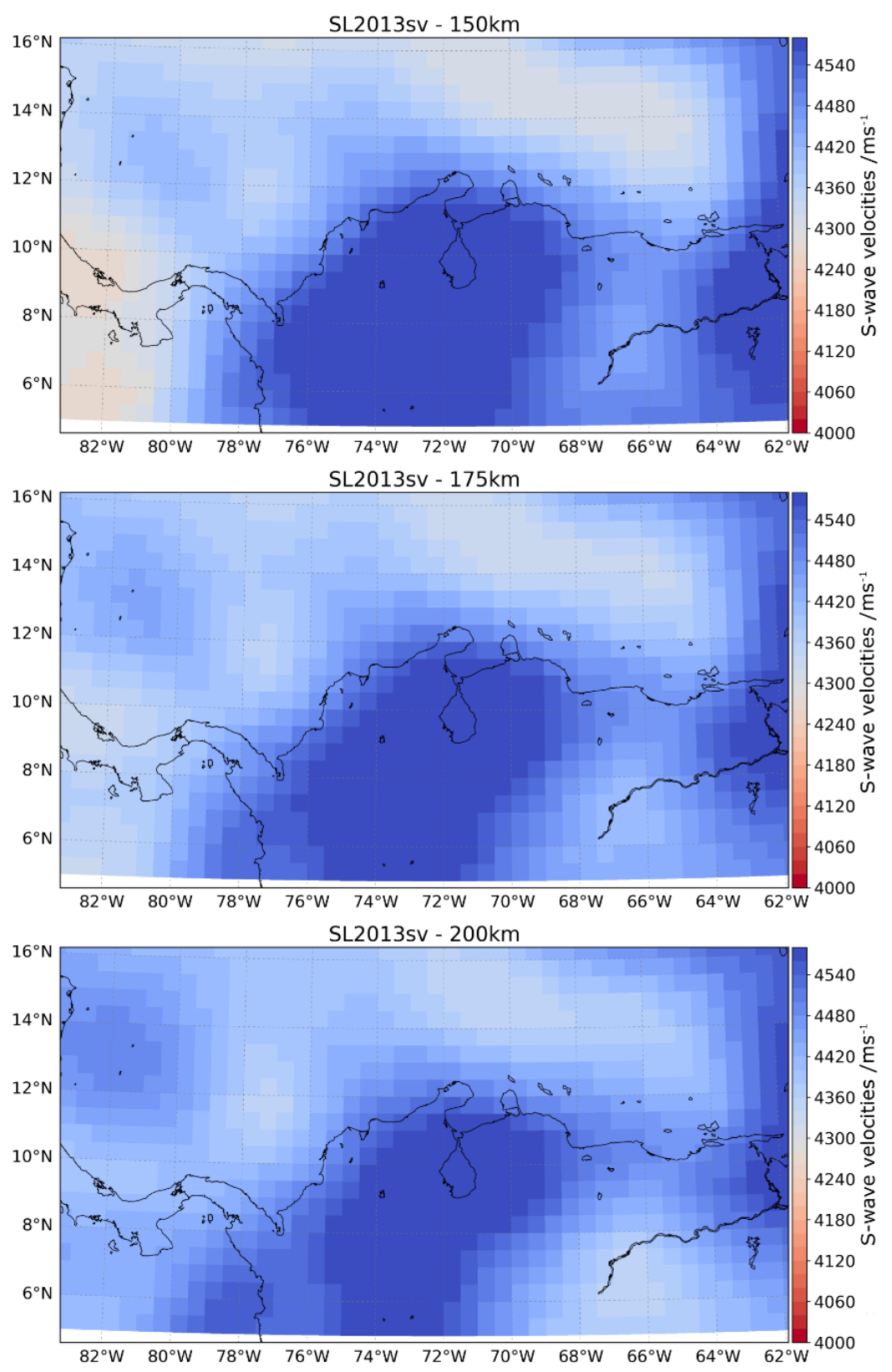

Figure S3. S-wave velocities from the SL2013sv model (Schaeffer and Lebedev, 2013). Each map represents one mantle depth, from 50 down to $200 \mathrm{~km}$, as used in the calculation of the mantle densities according to Gómez-García et al. (2019a,b). The original cell size of the tomographic data is $0.5^{\circ}$. The resulting mantle densities are shown in Figure $\mathbf{S 4}$. 


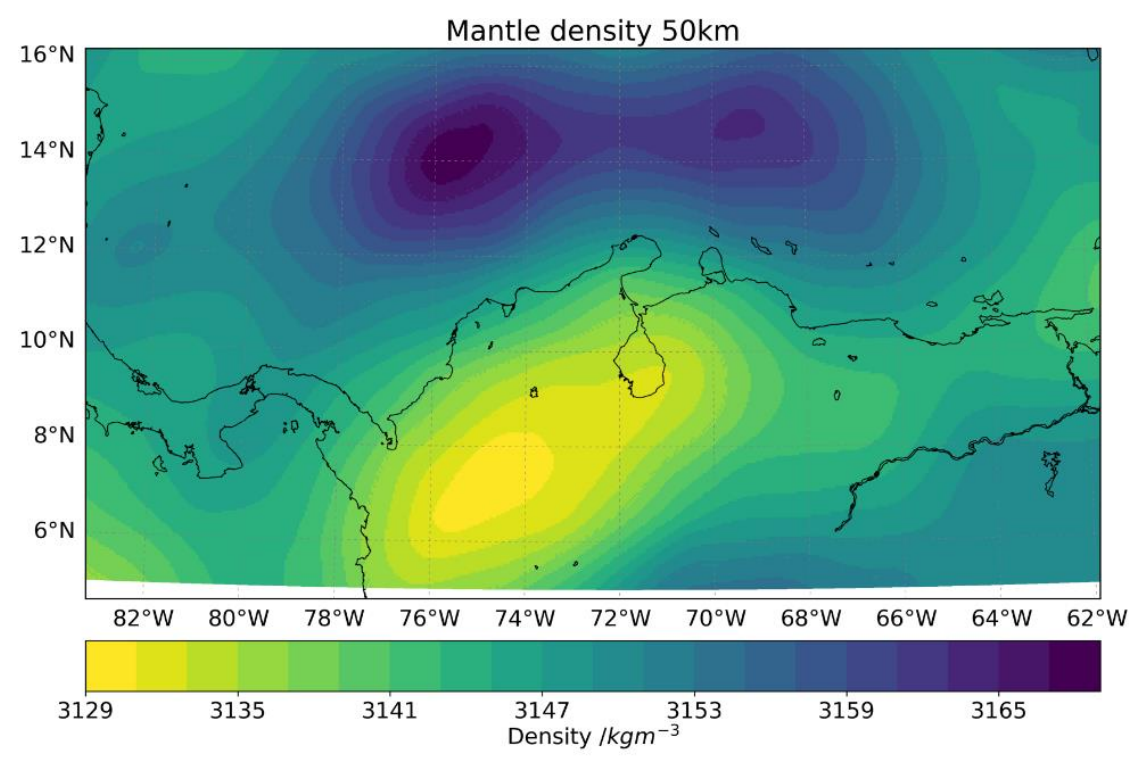

Mantle density $75 \mathrm{~km}$

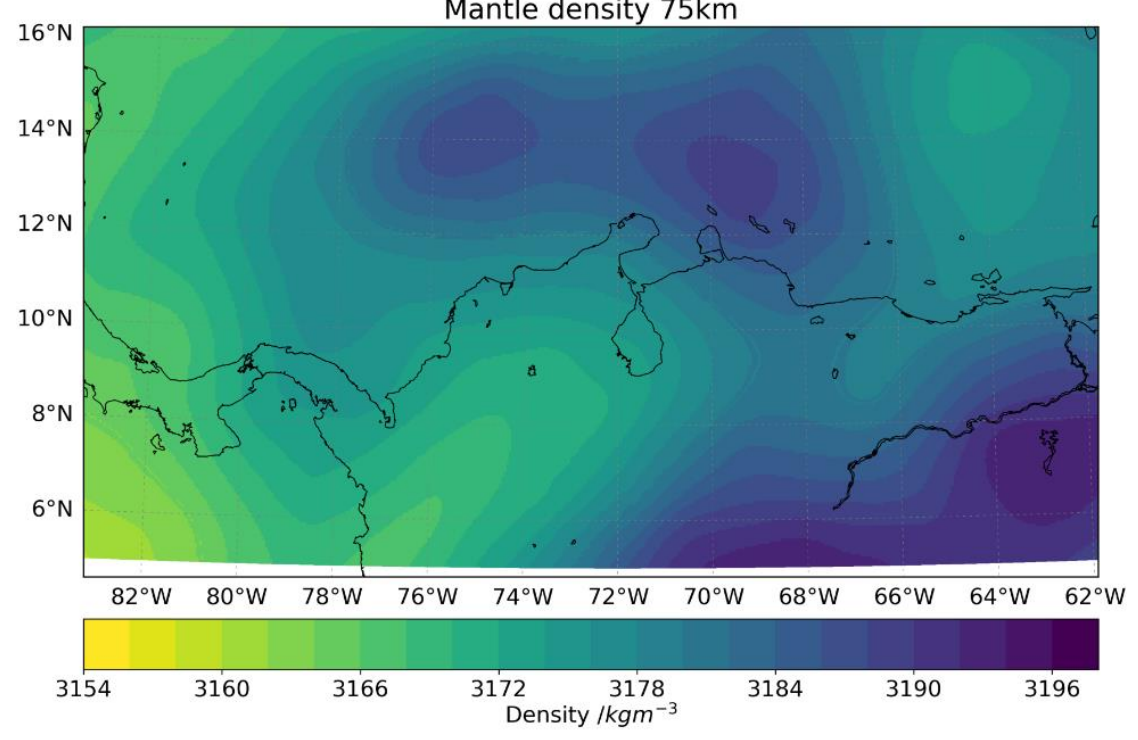

Mantle density $100 \mathrm{~km}$

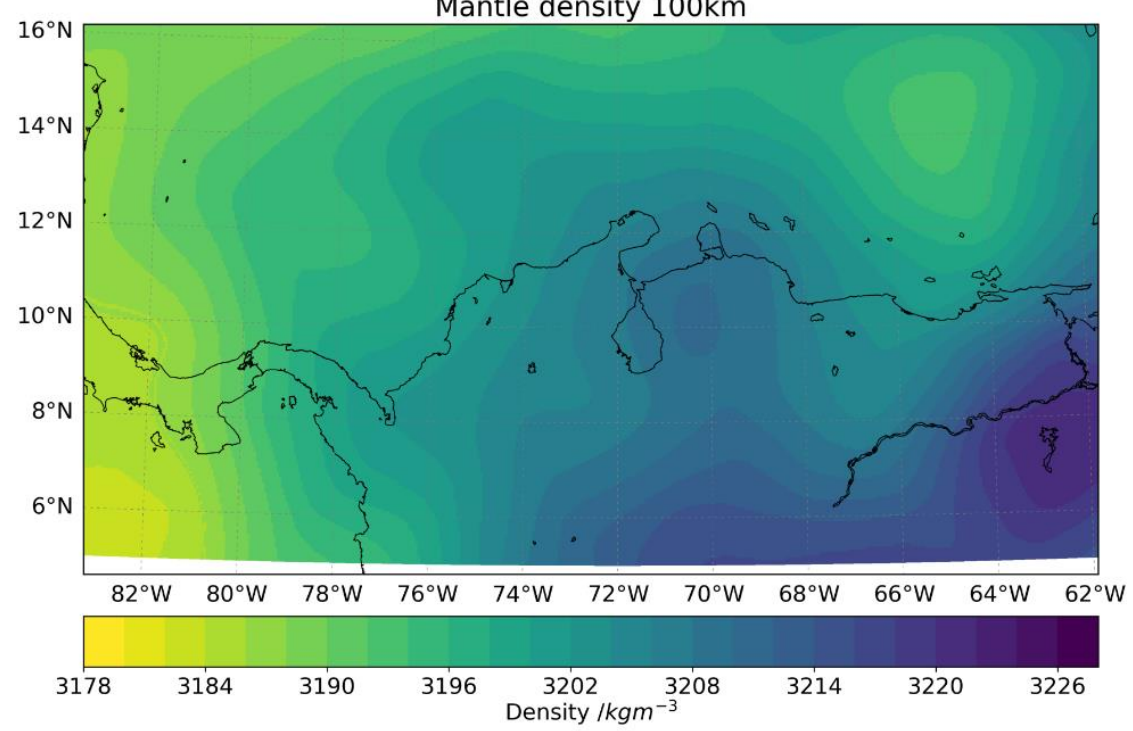




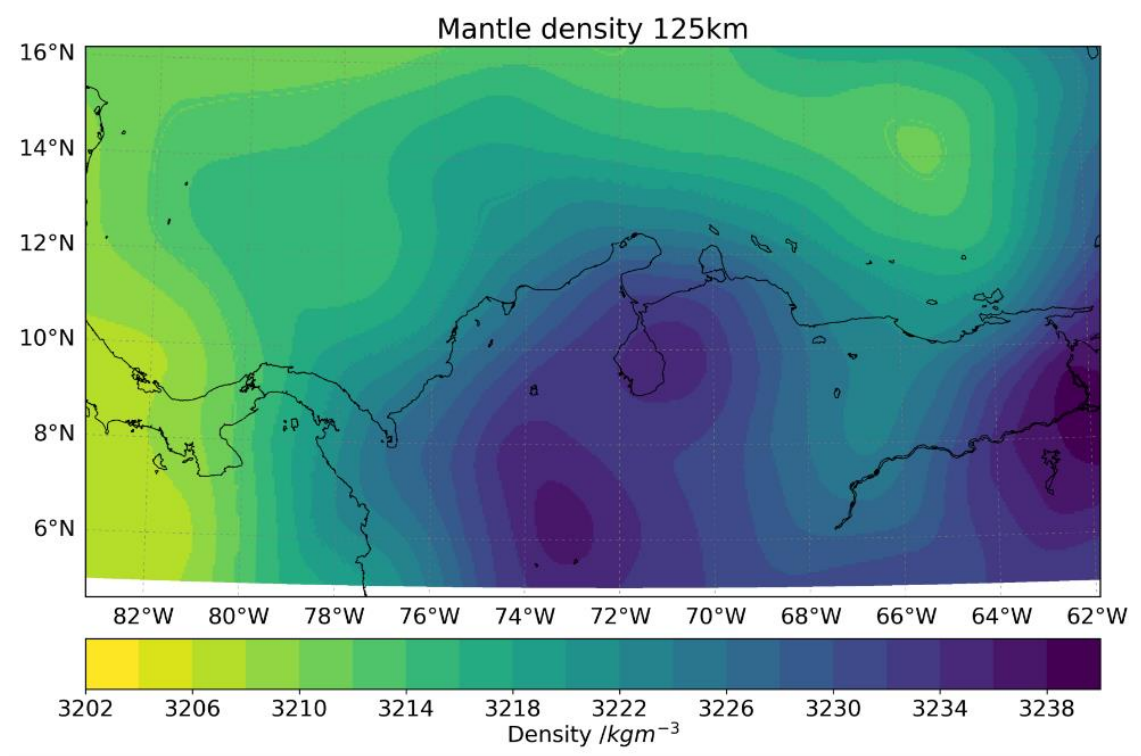

Mantle density $150 \mathrm{~km}$

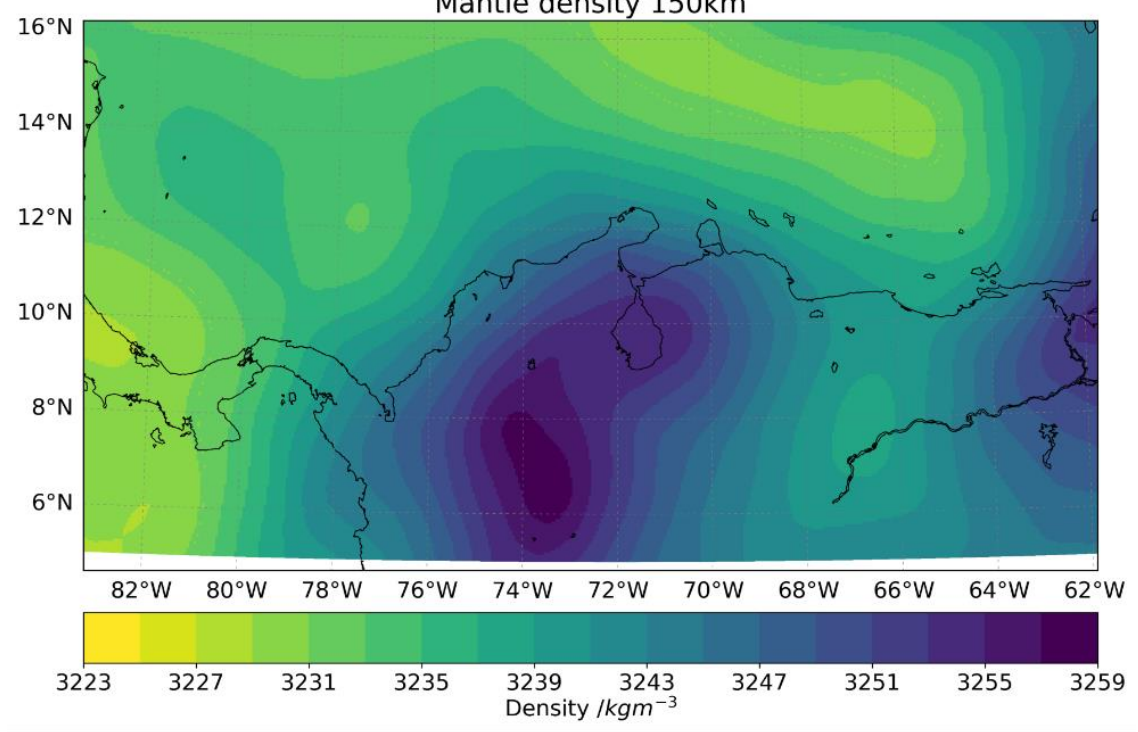

Mantle density $175 \mathrm{~km}$

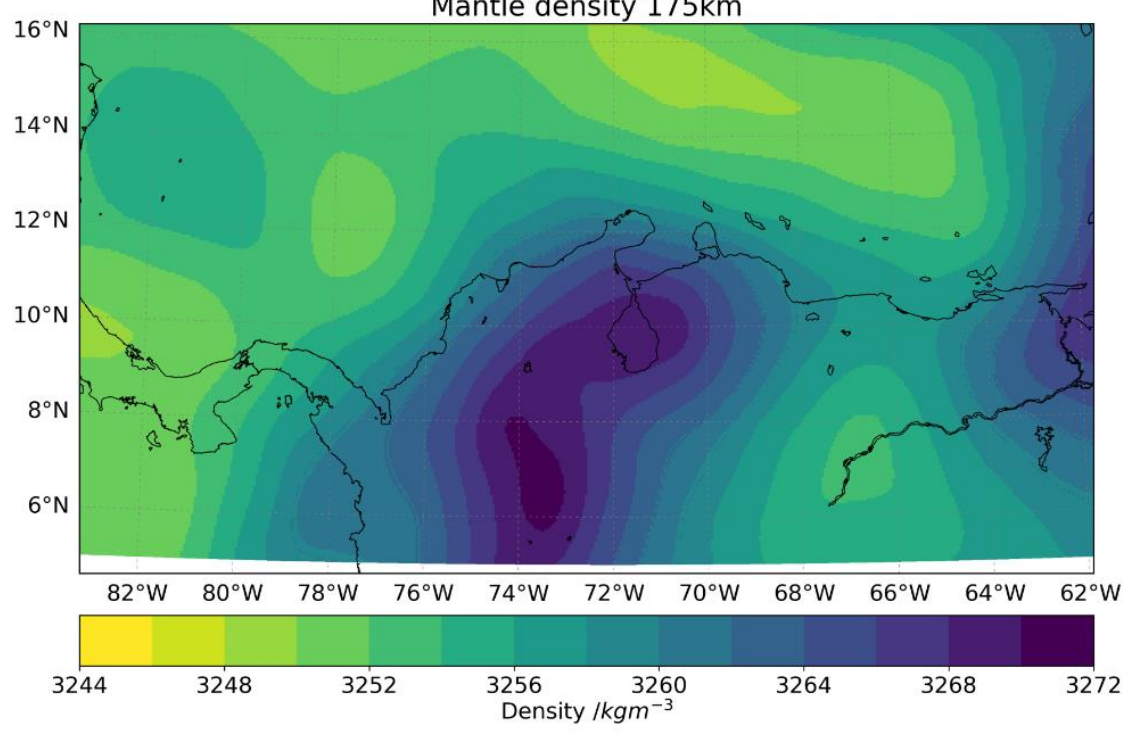




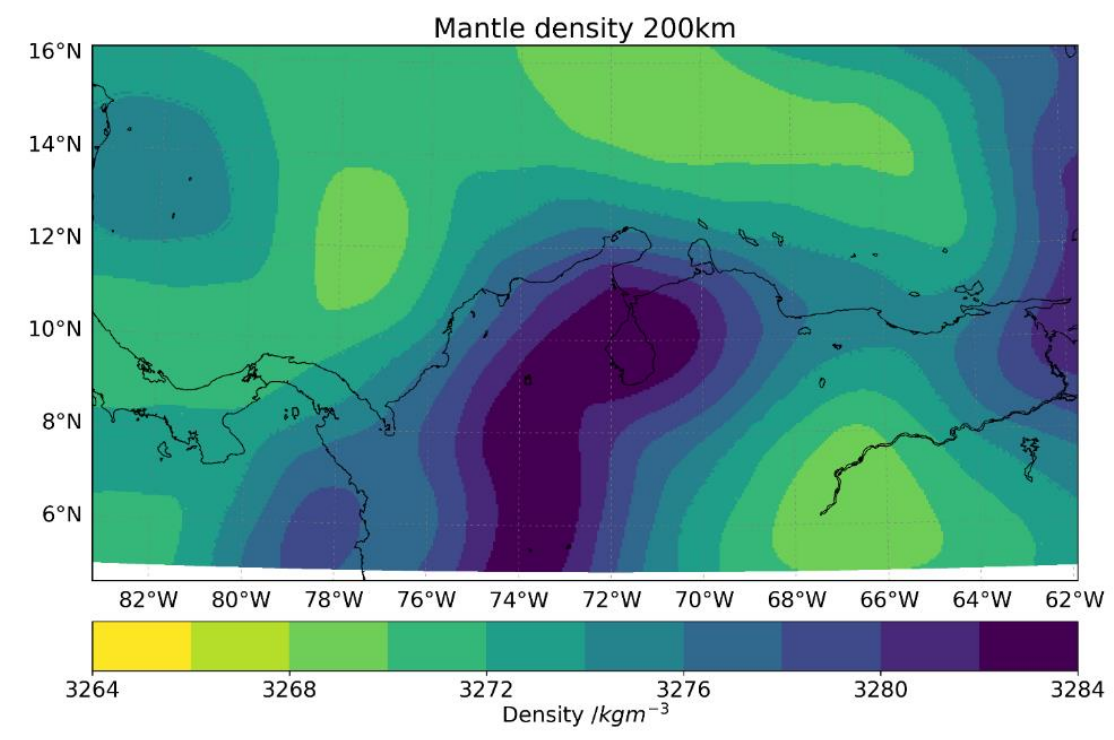

Figure S4. Mantle densities obtained from the S-wave velocity anomalies of Schaeffer and Lebedev (2013) using Meeßen (2017) and Goes et al. (2000). 
S4. Histograms of the gravity residuals of the different tested lithospheric configurations

(a)

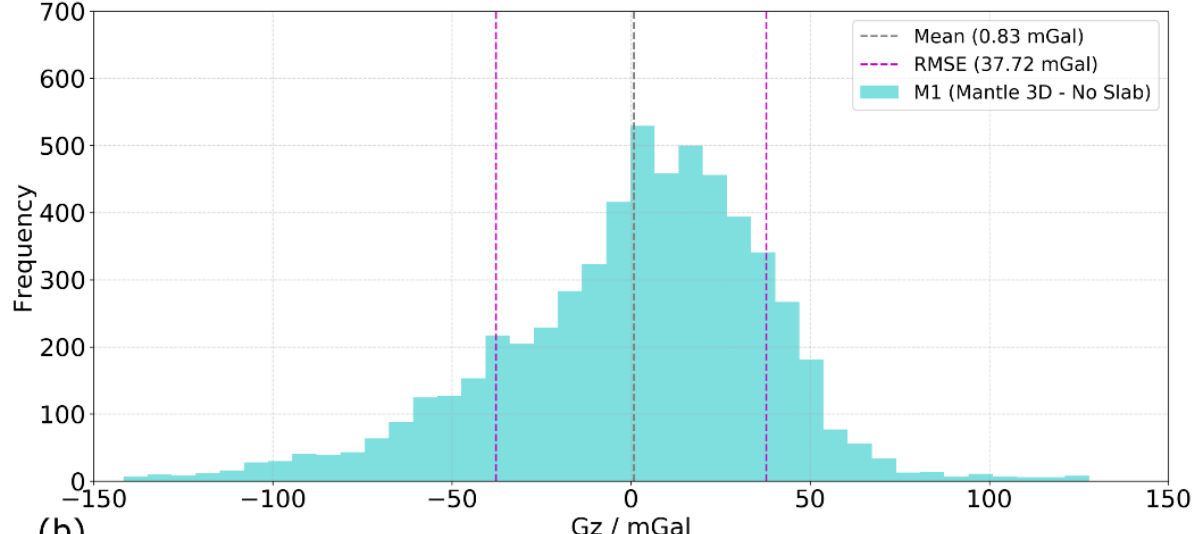

(b)

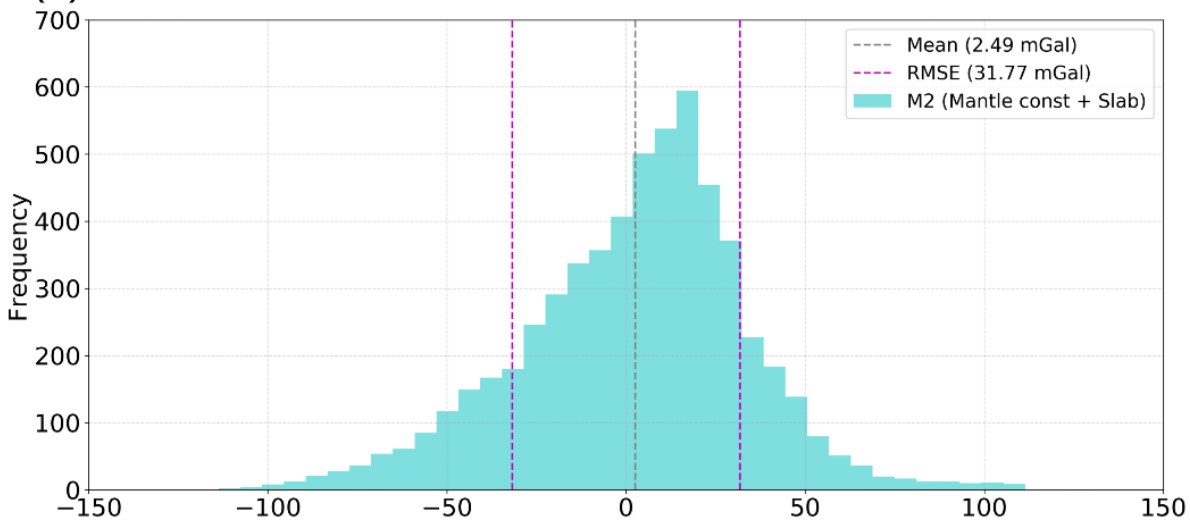

(c)

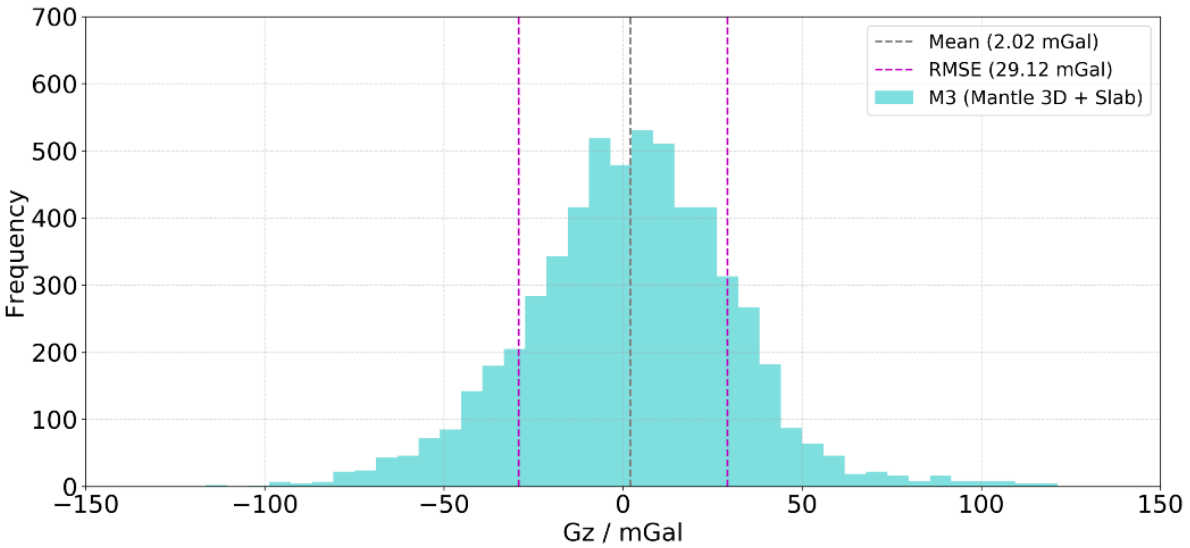



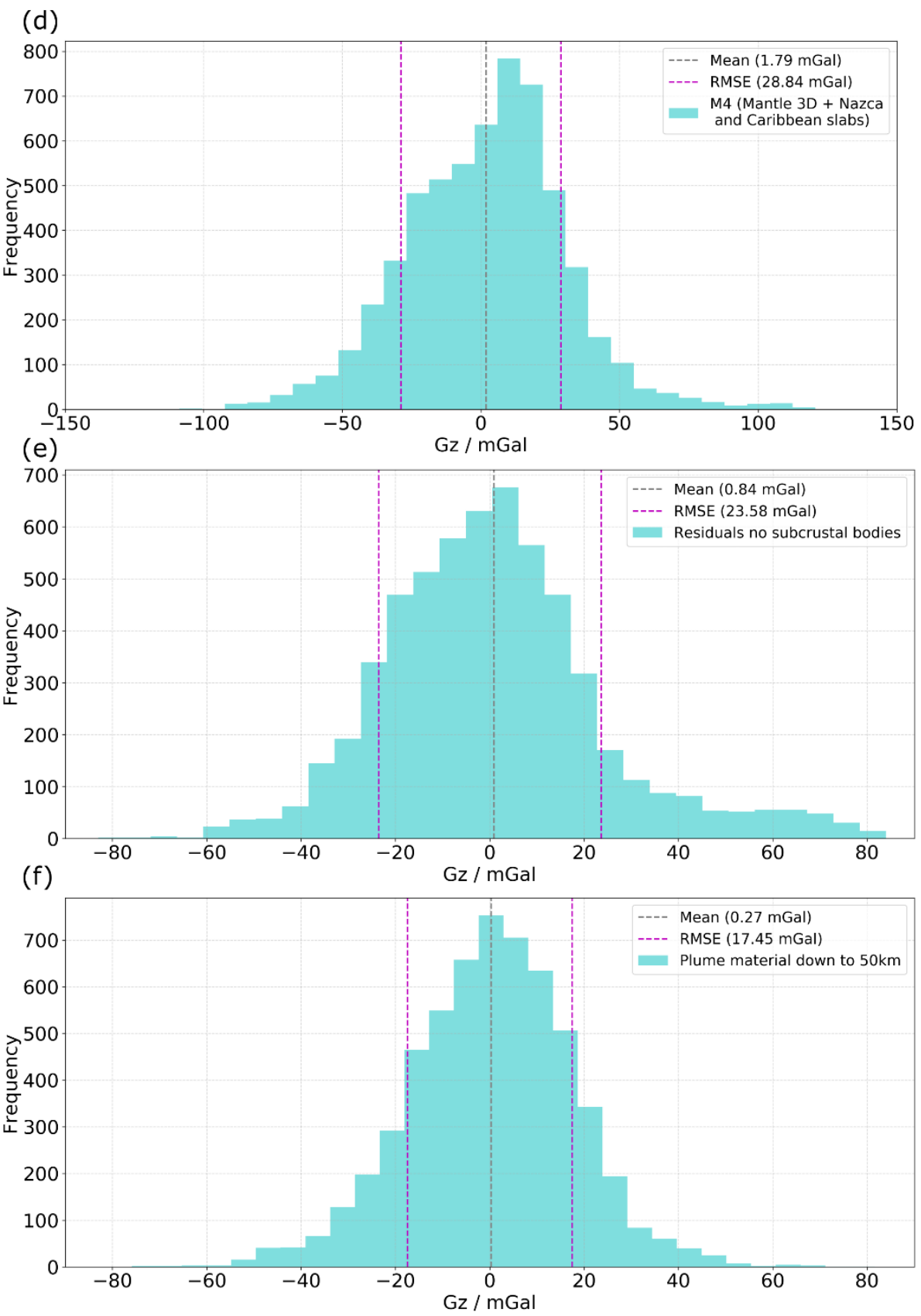

Figure S5. Histograms of the gravity residuals for the four tested models. (a) Model M1. (b) Model M2. (c) Model M3. (d) Model M4. (e) Model without subcrustal bodies (see Figure 7 (b) on manuscript). (f) Model including the subcrustal bodies down to 50 km depth (final model). See Table $\mathbf{S 1}$ and Table 2 for a detailed description of the tested mantle's density configurations. 
S5. Gravity response when the subcrustal bodies are located from the Moho down to $\mathbf{2 5} \mathbf{~ k m}$ depth
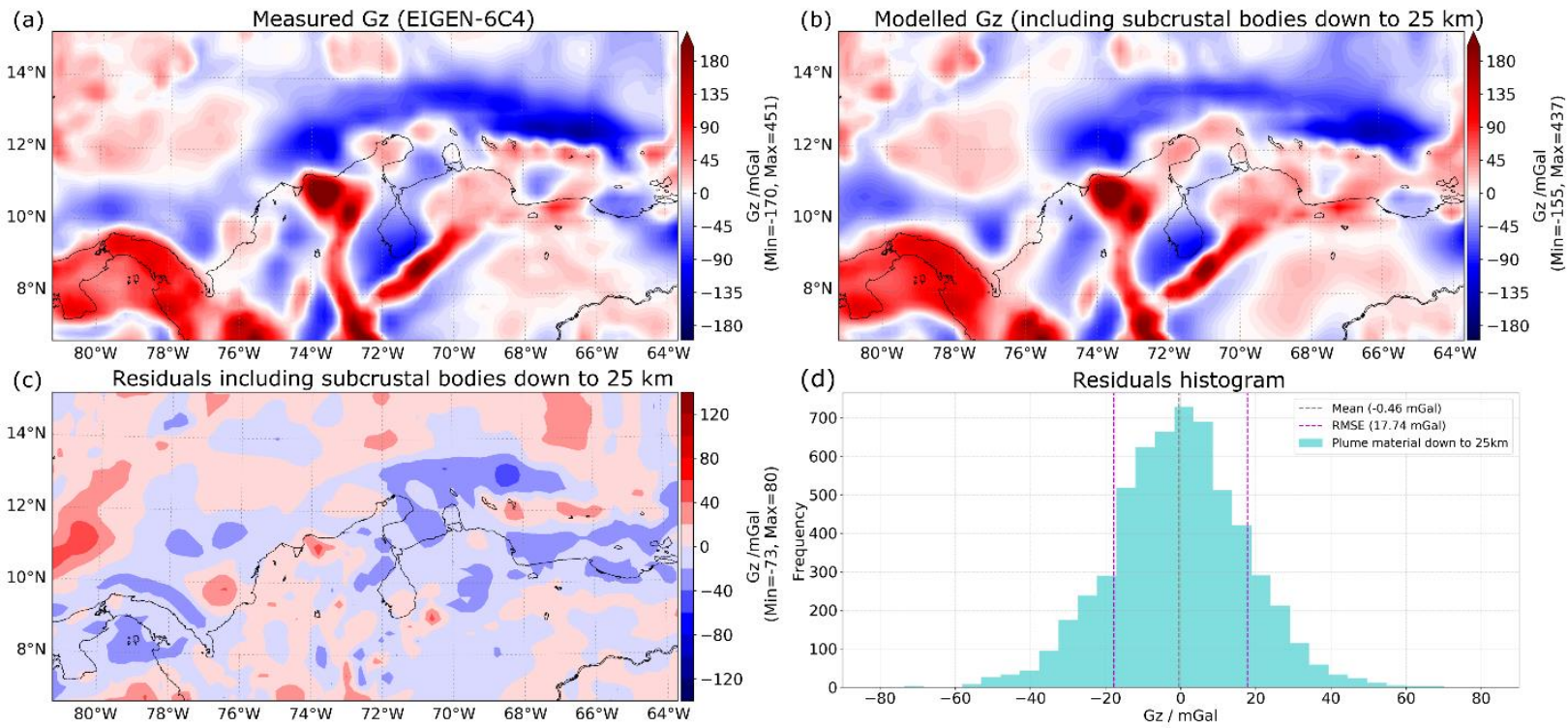

Figure S6. Gravity anomalies (Gz): (a) measurements available in the EIGEN-6C4 dataset at $10 \mathrm{~km}$ height (Förste et al., 2014; Ince et al., 2019). (b) Gz after including the subcrustal bodies only down to $25 \mathrm{~km}$ depth. (c) Associated residuals. (d) Histogram of the residuals associated to this lithospheric configuration. 
S6. Vertical relation between the subcrustal bodies (down to $50 \mathrm{~km}$ ) and the mantle density at 25, 50 and $75 \mathrm{~km}$ depth

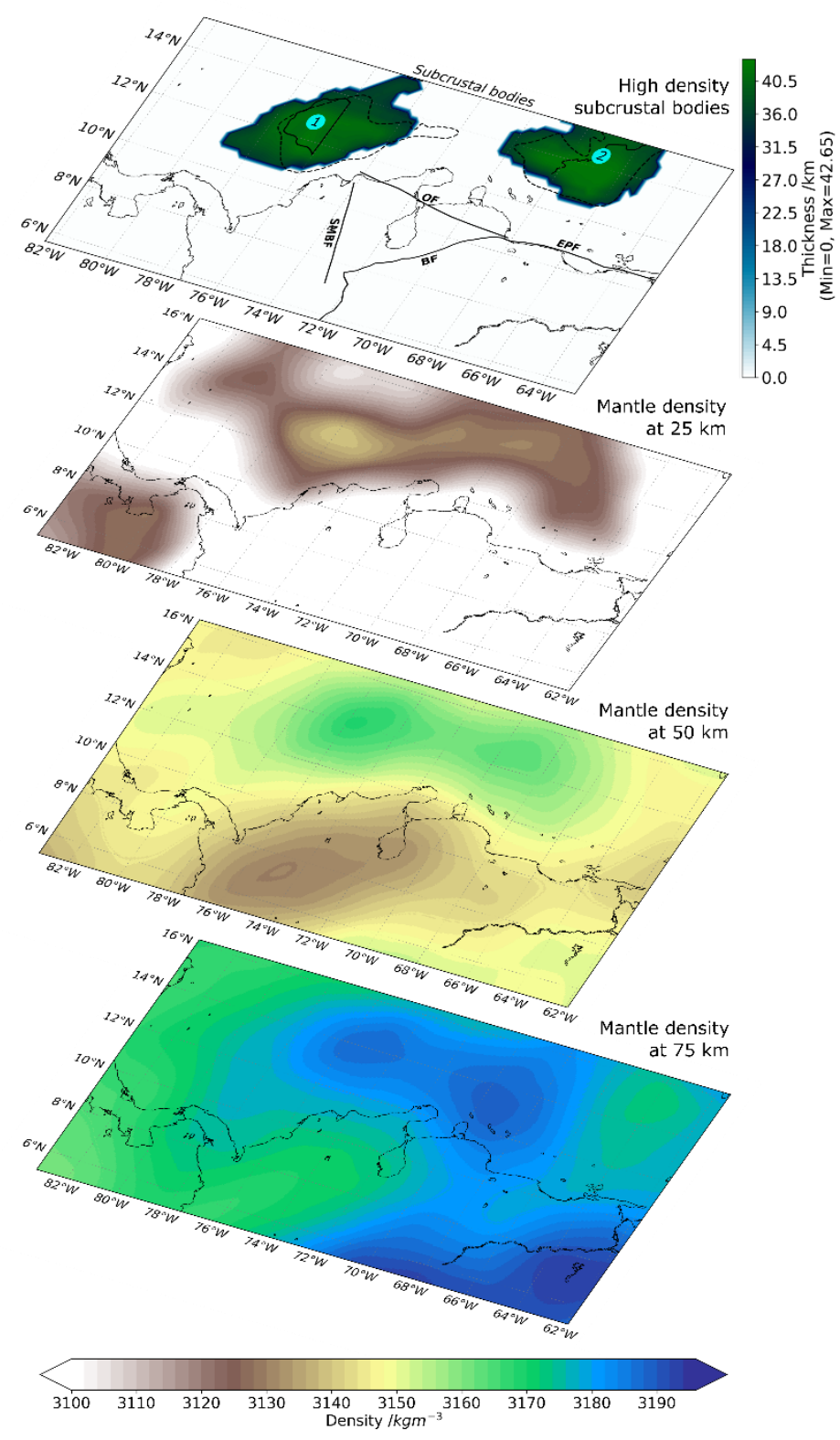

Figure S7. The high-density subcrustal bodies (uppermost panel) seem to be a continuation of a high-density mantle zone in the upper mantle. This trend can be followed from $25 \mathrm{~km}$ depth (where a maximum density of $\sim 3150 \mathrm{~kg} \mathrm{~m}^{-3}$ is calculated), down to $75 \mathrm{~km}$, where the highest density of the Caribbean upper mantle is reached $\left(\sim 3190 \mathrm{~kg} \mathrm{~m}^{-3}\right)$. 


\section{References}

Förste, C., Bruinsma, S., Abrikosov, O., Lemoine, J.-M., Marty, J.-C., Flechtner, F., Balmino, G., Barthelmes, F. and Biancale, R.: EIGEN-6C4 The latest combined global gravity field model including GOCE data up to degree and order 2190 of GFZ Potsdam and GRGS Toulouse, GFZ Data Serv., doi:http://dx.doi.org/10.5880/icgem.2015.1, 2014.

Gómez-García, A. ., Meeßen, C., Scheck-Wenderoth, M., Monsalve, G., Bott, J., Bernhardt, A. and Bernal, G.: Scripts to calculate the Vertical Gravity Gradients response of a 3D lithospheric model using spherical coordinates: the Caribbean oceanic domain as a case study, , doi:http://doi.org/10.5880/GFZ.4.5.2019.002, 2019a.

Gómez-García, Á. M., Meeßen, C., Scheck-Wenderoth, M., Monsalve, G., Bott, J., Bernhardt, A. and Bernal, G.: 3-D modeling of Vertical Gravity Gradients and the delimitation of tectonic boundaries: the Caribbean oceanic domain as a case study, Geochemistry, Geophys. Geosystems, 20(11), 5371-5393, doi:10.1029/2019GC008340, 2019b.

Hayes, G. P., Moore, G. L., Portner, D. E., Hearne, M., Flamme, H., Furtney, M. and Smoczyk, G. M.: Slab2, a comprehensive subduction zone geometry model - Supplementary material, Science (80-. )., 362(6410), 58-61, doi:10.1126/science.aat4723, 2018.

Ince, E. S., Barthelmes, F., Reißland, S., Elger, K., Förste, C., Flechtner, F. and Schuh, H.: ICGEM - 15 years of successful collection and distribution of global gravitational models, associated services, and future plans, Earth Syst. Sci. Data, 11, 647-674, doi:10.5194/essd-2019-17, 2019.

Laske, G., Masters, G., Ma, Z. and Pasyanos, M. E.: CRUST1.0 : An Updated Global Model of Earth's Crust, Geophys. Res. Abstr., 15, Abstract EGU2013--2658 [online] Available from: http://igppweb.ucsd.edu/ gabi/rem.html, 2013.

Mora, J. A., Oncken, O., Le Breton, E., Ibánez-Mejia, M., Faccenna, C., Veloza, G., Vélez, V., de Freitas, M. and Mesa, A.: Linking Late Cretaceous to Eocene tectonostratigraphy of the San Jacinto fold belt of NW Colombia with Caribbean plateau collision and flat subduction, Tectonics, 36(11), 2599-2629, doi:10.1002/2017TC004612, 2017.

Reguzzoni, M. and Sampietro, D.: GEMMA: An Earth crustal model based on GOCE satellite data, Int. J. Appl. Earth Obs. Geoinf., 35(PA), 31-43, doi:10.1016/j.jag.2014.04.002, 2015.

Sæther, B.: Improved estimation of subsurface magnetic properties using minimum mean-square error methods, Norwegian University of Science and Technology., 1997.

Schaeffer, A. J. and Lebedev, S.: Global shear speed structure of the upper mantle and transition zone, Geophys. J. Int., 194(1), 417-449, doi:10.1093/gji/ggt095, 2013.

Schmidt, S., Plonka, C., Götze, H. J. and Lahmeyer, B.: Hybrid modelling of gravity, gravity gradients and magnetic fields, Geophys. Prospect., 59(6), 1046-1051, doi:10.1111/j.1365-2478.2011.00999.x, 2011.

Weatherall, P., Marks, K. M., Jakobsson, M., Schmitt, T., Tani, S., Arndt, J. E., Rovere, M., Chayes, D., Ferrini, V. and Wigley, R.: A new digital bathymetric model of the world's oceans, Earth Sp. Sci., 2, 331-345, doi:10.1002/2015EA000107, 2015. 